\title{
EFEKTIFITAS PEMBELAJARAN DARING GOOGLE CLASSROOM PADA MAHASISWA ILMU KOMUNIKASI UNIVERSITAS SARIPUTRA INDONESIA TOMOHON
}

\author{
Apriles Mandome, Aks Thomas Puasa \\ Universitas Sariputra Indonesia Tomohon, Sulawesi Utara \\ apriles@unsrittomohon.ac.id, akspuasa@unsrittomohon.ac.id
}

\begin{abstract}
Abstrak
Pembelajaran daring adalah sebuah bentuk pembelajaran yang saat ini sudah banyak diimplementasikan di dalam cara belajar di Indonesia. Hal ini dilakukan karena beberapa alasan, diantaranya adalah karena faktor kesibukan disamping kemajuan teknologi yang harus diadopsi. Hal ini juga sudah dilakukan di lingkungan Universitas Sariputra Indonesia Tomohon, khususnya pada Program Studi Ilmu Komunikasi Fakultas Ilmu Sosial melalui layanan atau aplikasi yang disediakan Google yaitu Google Classroom. Namun demikian sejauh ini belum diketahui efektifitas pembelajaran daring yang terjadi pada Program Studi Ilmu Komunikasi Fakultas Ilmu Sosial UNSRIT yang sudah dilakukan. Sehingga dapat diputuskan apakah pembelajaran daring akan terus dilakukan atau dihentikan dan apakah pembelajaran daring ini dapat diterapkan secara luas di UNSRIT atau tidak. Oleh karena itu denga menggunakan metode deskriptif penelitian dilakukan untuk mengetahui efektifitas implementasi pembelajaran daring Google Classroom pada mahasiswa Ilmu Komunikasi UNSRIT. Lokasi dan sampel penelitian adalah mahasiswa Ilmu Komunikasi UNSRIT. Teknologi yang dihasilkan melalui penelitian adalah terukurnya secara jelas efektifitas pembelajaran daring google classroom pada mahasiswa maupun dosen sehingga sistem pembelajaran daring dapat dikembangkan secara kontinu di dalam menunjang proses pendidikan di perguruan tinggi.
\end{abstract}

Kata Kunci: Efektifitas, Pembelajaran daring, Google Classroom

\begin{abstract}
Online learning is a form of learning that is currently being implemented in many learning methods in Indonesia. This is done for several reasons, including business as well as technological advances that must be adopted. This has also been done in the Sariputra Indonesia Tomohon University environment, especially in the Communication Science Department of the Faculty of Social Sciences through services or applications provided by Google, namely Google Classroom. However, so far it has not been known the effectiveness of online learning in the Communication Study Program of the Faculty of Social Sciences, UNSRIT. So it can be decided whether online learning will continue or stop and whether this online learning can be widely applied at UNSRIT or not. Therefore, by using a descriptive method, this research was carried out to determine the effectiveness of the implementation of Google Classroom online learning in UNSRIT Communication Science students. The location and research samples were the students of Communication Studies UNSRIT. The technology that is to be produced through this research is a clear measurement of the effectiveness of google classroom online learning for students and lecturers so that the online learning system could be developed continuously to support the education process in higher education.
\end{abstract}

Keywords: Effectiveness, Online learning, Google Classroom. 


\section{PENDAHULUAN}

Perkembangan ilmu pengetahuan dan teknologi dewasa ini mengalami peningkatan signifikan. Khususnya pemanfaatan teknologi dalam pemenuhan kebutuhan sehari-hari. Hasil survei dari Asosiasi Penyelenggara Jaringan Internet Indonesia (APJII) pada tahun 2016 pengguna internet di Indonesia sebanyak 132,7 juta orang. Dimana total penduduk Indonesia 256,2 juta orang, artinya pengguna internet di Indonesia sebanyak 51,8\% ${ }^{1}$. Salah satu indikasi pemanfaatan jaringan internet yang makin massif adalah penggunaan komputer dan telepon genggam. Rentang usia pun sangat bervariasi yang sesuai dengan pemanfaatan masing-masing seperti media sosial, hiburan, permainan, menjelajah (browsing), transaksi jual-beli, dan sebagainya.

Hal ini juga berdampak pada dunia pendidikan sehingga sejak tahun 2014 Direktorat Pembelajaran dan Kemahasiswaan, Direktorat Jenderal Pendidikan Tinggi mengembangkan program Pembelajaran Daring Indonesia Terbuka dan Terpadu (PDITT), yang diluncurkan tanggal 15 Oktober 2014 oleh Wakil Presiden Boediono. Pada 18 September 2016, berganti nama menjadi Sistem Pembelajaran Daring (SPADA) .

Program SPADA Indonesia pada dasarnya adalah implementasi dari Undang-Undang Republik Indonesia Nomor 20 Tahun 2003 tentang Sistem Pendidikan Nasional, UU No. 12 Tahun 2012 tentang Pendidikan Tinggi, dan Peraturan Menteri Pendidikan dan Kebudayaan Nomor 109 Tahun 2013 tentang Penyelenggaraan Pendidikan Jarak Jauh pada Pendidikan Tinggi. Dimana dalam Permendikbud 109 tahun 2013, menyatakan bahwa salah satu lingkup pendidikan jarak jauh yaitu lingkup mata kuliah.

Implementasi pembelajaran daring yang diterapkan pemerintah disambut dengan sangat positif oleh dunia pendidikan di Indonesia. Perguruan tinggi baik negeri maupun swasta berlomba-lomba melaksanakan sistem perkuliahan daring baik secara mandiri melalui sistem elearning yang dibuat seperti misalnya e-learning Unpad dan Scele UI maupun dengan menggunakan aplikasi yang disediakan oleh perusahaan-perusahaan teknologi dan internet seperti google dengan aplikasi google classroom khususnya bagi perguruan-perguruan tinggi yang belum memiliki sumber daya di bidang teknologi.

\footnotetext{
${ }^{1}$ Vicky Dwi Wicaksono \& Putri Rachmadyanti, 2017, Pembelajaran Blended Learning Melalui Google Classroom di Sekolah Dasar. Prosiding Seminar Nasional Pendidikan PGSD UMS \& HDPGSDI Wilayah Jawa, h. 513521. ISBN 978-602-70471-2-9
} 
Sistem perkuliahan daring dengan menggunakan google classroom saat ini juga telah coba diimplementasikan dalam perkuliahan pada Program Studi Ilmu Komunikasi di Universitas Sariputra Indonesia Tomohon. Selain untuk menjawab tuntutan kemajuan teknologi, implementasi ini juga diperlukan sebagai perwujudan visi misi Universitas Sariputra Indonesia Tomohon yaitu menghasilkan sarjana-sarjana yang sadar iptek dan berwawasan luas. Namun demikian, hingga saat ini belum terukur secara jelas dampak atau lebih tepatnya efektifitas implementasi pembelajaran daring melalui google classroom ini bagi proses pembelajaran itu sendiri maupun bagi kemampuan dan semangat belajar mahasiswa di Universitas Sariputra Indonesia Tomohon.

Oleh karena itu penelitian ini sangat penting untuk dilakukan agar dapat memberikan dasar bagi implementasi pembelajaran daring di perguruan-perguruan tinggi baik negeri maupun swasta dan Untuk mengetahui bagaimana proses implementasi pembelajaran daring google classroom pada Program Studi Ilmu Komunikasi Universitas Sariputra Indonesia Tomohon serta Untuk mengetahui efektifitas pembelajaran daring google classroom pada proses belajar mengajar dan pada minat belajar mahasiswa pada Prodi Ilmu Komunikasi Universitas Sariputra Indonesia Tomohon.

\section{KAJIAN TEORI}

\section{Pembelajaran Daring}

Pembelajaran Daring merupakan program penyelenggaraan kelas pembelajaran dalam jaringan untuk menjangkau kelompok target yang masif dan luas. Manfaat pembelajaran daring diantaranya adalah; meningkatkan mutu pendidikan dan pelatihan dengan memanfaatkan multimedia secara efektif dalam pembelajaran, meningkatkan keterjangkauan pendidikan dan pelatihan yang bermutu melalui penyelenggaraan pembelajaran dalam jaringan dan menekan biaya penyelenggaraan pendidikan dan pelatihan yang bermutu melalui pemanfaatan sumber daya bersama. Menurut Yusuf Bilfaqih dan Nur Qomarudin berdasar tren yang berkembang, Pembelajaran Daring memiliki karakteristik yang utama sebagai berikut ${ }^{2}$ :

1. Daring. Pembelajaran ini diselenggarakan melalui internet dengan menggunakan aplikasi yang telah tersedia atau dibangun oleh perguruan tinggi. Dalam metode pembelajaran 
daring ini maka materi dapat disajikan dalam berbagai bentuk, diantaranya melalui rekaman video, slideshow dan lain sebagainya.

2. Masif. Oleh karena pembelajaran ini menggunakan jaringan internet maka jumla pesertanya menjadi tidak terbatas.

3. Terbuka. Sistem terbuka bagi kalangan manapun dari beragam profesi. Siapa saja, dengan latar belakang apa saja dan pada usia berapa saja, dapat diajngkau dan dapat belajar melalui sistem pembelajaran daring ini.

Adapun peraturan dan undang-undang yang menjamin pelaksanaan dan keberlanjutan program pembelajaran, pendidikan dan pelatihan secara daring, di antaranya adalah sebagai berikut (Bilfaqih \& Qomarudin, 2015):

1. Undang-Undang No. 20 tahun 2003 tentang Sistem Pendidikan Nasional;

2. Peraturan Pemerintah No. 19 tahun 2005 tentang Standar Nasional Pendidikan;

3. Undang-Undang Nomor 14 tahun 2005 tentang Guru dan Dosen:

4. Peraturan Presiden Detiknas tentang Pemanfaatan TIK (KEPRES RI NOMOR 20 TAHUN 2006)

5. Dokumen Rencana Strategis Direktorat Jenderal Pendidikan Tinggi, Departemen Pendidikan Nasional Tahun 2010-2014;

6. Renstra Strategis Direktorat Jenderal Pendidikan Tinggi, Departemen Pendidikan Nasional Tahun 2010-2014.

\section{Google Classroom}

Google classroom adalah sebuah layanan berbasis internet yang disediakan oleh Google sebagai sebuah sistem e-learning. Layanan ini didesain untuk membantu pengajar membuat dan membagikan tugas kepada pelajar secara paperless atau tanpa menggunakan kertas (Abdul, 2016). Google Classroom merupakan sebuah aplikasi yang memungkinkan terciptanya ruang kelas di dunia maya. Selain itu, google classroom bisa menjadi sarana distribusi tugas, submit tugas bahkan menilai tugas-tugas yang dikumpulkan (Herman, 2014).

Dengan demikian aplikasi atau layanan ini sangat membantu baik pengajar maupun pelajar dalam sebuah kelas oleh karena layanan ini memberikan banyak kemudahan dalam

${ }^{2}$ Yusuf Bilfaqih \& M. Nur Qomarudin, 2015. Esensi Pengembangan pembelajaran Daring, Ed. 1, Cet. 1. 
pelaksanaan pembelajaran. Pembelajaran dapat dilaksanakan dimanapun, kapanpun dan hanya bermodalkan komputer atau bahkan handphone. Selain murah, langkah-langkah untuk dapat menggunakan layanan atau aplikasi ini juga sangat mudah dan gampang dipahami. Berikut garis besar penggunaan layanan atau aplikasi Google Classroom:

1. Menyiapkan akun google dan jika belum memiliki akun google maka harus terlebih dahulu membuat akun google dimaksud.

2. Membuka www.google.com dan mencari google classroom atau bisa langsung www.googleclassroom.google.com kemudian melakukan sign in.

3. Setelah itu dapat melanjutkan membuat kelas baru dan menekan tanda + pada sudut kanan atas tampilan google classroom

4. Undang siswa untuk bergabung dengan kelas yang telah dibuat yaitu dengan menekan keterangan people pada bagian tengah atas tampilan kelas kemudia menekan ikon orang bersa tanda + pada bagian kanan tampilan kelas.

5. Setelah kelas terbentuk maka selanjutnya dapat melakukan pembelajaran daring melalui layanan atau aplikasi ini, diantaranya memberikan materi, memberikan tugas, mereview tugas dan lain sebagainya dengan menekan fitur yang tersedia pada bagian atas dari google classroom yang sudah ada.

Yogyakarta: Deepublish

\section{METODE PENELITIAN}

Metode penelitian yang digunakan dalam penelitian ini adalah metode deskriptif kualitatif. Metode deskriptif bertujuan untuk membuat gambaran secara sistematis, faktual dan akurat mengenai hubungan antar fenomena yang diselidiki. Yang menjadi lokasi dari penelitian ini adalah Universitas Sariputra Indonesia Tomohon yang beralamat di jalan Perlombaan 2 Kakaskasen, Tomohon Utara, Kota Tomohon. Yang menjadi subyke pada penelitian ini adalah Mahasiswa pada Program Studi Ilmu Komunikasi Fakultas Ilmu Sosial Universitas Sariputra Indonesia Tomohon yang menggunakan Google Classroom.

Adapun teknik pengumpulan data yang akan dilakukan dalam penelitian ini adalah melalui observasi dan wawancara. Observasi dilakukan langsung di lapangan yang dalam hal ini pada mahasiswa Ilmu Komunikasi Fakultas Ilmu Sosial UNSRIT. Wawancara dilakukan secara 
terukur dengan bentuk wawancara tertutup kepada mahasiswa Ilmu Komunikasi Fakultas Ilmu Sosial Unsrit. Ada empat evaluasi melalui proses wawancara yang akan digunakan dalam penelitian untuk mengukur keefektifan penggunaan Google Classroom di Program Studi Ilmu Komunikasi Fakultas Ilmu Sosial UNSRIT.

1. Reaction. Hasil dari tahap ini akan menunjukkan kepuasan pengguna Google Classroom. Untuk mendapatkan hasilnya, setiap responden akan mengisikan kuesioner yang berisi pertanyaan mengenai sejauh mana pengaruh pemanfaatan Google Classroom telah dicapai untuk membantu proses belajar mengajar.

2. Learning. Hasil dari proses kedua ini akan menunjukkan interaksi pengguna Google Classrom dalam menggunakan Google Classroom itu sendiri. Apakah cara menggunakan Google Classroom dapat masuk di akal untuk digunakan di berbagai kalangan jurusan yang menggunakannya pada Program Studi Ilmu Komunikasi Fakultas Ilmu Sosial UNSRIT. Untuk mengetahui hasil dari tahap kedua ini responden akan mengisikan kuesioner yang berisi pertanyaan mengenai cara penggunaan responden terhadap penggunaan / interaksi dengan aplikasi Google Classroom.

3. Behaviour. Hasil dari proses ketiga ini akan menunjukkan apakah perbedaan pengguna Google Classroom sesudah dan sebelum menggunakan Google Classroom. Untuk mengetahui hasil dalam tahap ini, peneliti akan memberikan kuesioner kepada mahasiswa maupun dosen, untuk mengisikan kuesioner. Kuesioner yang akan diberikan kepada dosen isinya akan berbeda dengan kuesioner yang akan diberikan kepada mahasiswa.

4. Result. Pada bagian ini akan dapat diukur hasil dari penggunaan google classroom pada Program Studi Ilmu Komunikasi Fakultas Ilmu Sosial UNSRIT apakah sudah efektif atau tidak.

Analisis data selama di lapangan akan dilakukan secara interaktif dan berlangsung terus menerus sampai tuntas sehingga datanya sudah jenuh sebagaimana yang diungkapkan oleh Miles dan Huberman ${ }^{3}$. Oleh karena itu hal ini akan dilakukan melalui tiga unsur : reduksi data, penyajian data dan penarikan kesimpulan.

\footnotetext{
${ }^{3}$ Bungin, B., 2010. Penelitian Kualitatif. 1 ed. Jakarta: Kencana.
} 
Reduksi Data, Tujuan dari reduksi data adalah untuk memudahkan peneliti memahami data yang sudah dikumpulkan. Karena itu data yang dikumpulkan di lapangan, baik itu melalui observasi maupun wawancara akan dirangkum, dipilih menurut tingkat urgensinya, mengklasifikasikan sesuai fokus pada masalah dalam penelitian ini. Dalam penelitian ini aspek yang akan direduksi dari hasil observasi dan wawancara adalah bagaimana bagaimana penggunaan google classroom pada mahasiswa Ilmu Komunikasi Fakultas Ilmu Sosial UNSRIT dan sejauh mana mahasiswa sudah memahami penggunaan google classroom tersebut.

Penyajian Data, sebagaimana reduksi data diatas, maka proses penyajian data juga adalah bagian penting dalam proses tehnik analisis data bagi penelitian ini. Dalam proses ini, peneliti akan menyajikan data secara jelas dan singkat agar dapat dipahami secara mudah. Data yang sudah dikumpulkan akan disajikan dalam berbagai bentuk, diantaranya: gambar, matriks, catatan ringkas atau uraian, chart, grafik dan lain-lain.

Penarikan Kesimpulan, setelah melalui proses reduksi data, penyajian data, maka langkah selanjutnya adalah melakukan penarikan kesimpulan. Penarikan kesimpulan dilakukan melalui pengumpulan data yang telah dilakukan sebelum di lapangan dan selama dilapangan. Data yang sudah terkumpul direduksi dan disajikan menurut masalah dalam penelitian ini. Kesimpulan yang dihasilkan tentu saja merupakan jawaban atas masalah dalam penelitian ini dan untuk memenuhi tujuan penelitian ini. Langkah penarikan kesimpulan berdasarkan data-data awal akan bersifat sementara. Penarikan kesimpulan akhir yang akurat dan kredibel akan dilakukan pada akhir penelitian dengan didukung oleh data final yang valid, kuat dan konsisten sehingga kesimpulan yang diambil dapat dipertanggungjawabkan secara ilmiah dan akademis.

\section{PEMBAHASAN}

Perkembangan teknologi yang disertai dengan berbagai situasi saat ini membuat perubahan yang signifikan pada kehidupan manusia. Demikian halnya dengan dunia pendidikan, terjadi perubahan dalam interaksi antara guru dengan murid atau mahasiswa dengan dosen. Penggunaan teknologi yang semakin massif menjadikan interaksi secara langsung antara guru dengan murid ataupun mahasiswa dengan dosen semakin berkurang. Fenomena inipun terjadi di Universitas Sariputra Indonesia Tomohon khususnya pada Prodi Ilmu Komunikasi. 
Secara keseluruhan jumlah mahasiswa pad Podi Ilmu Komunikasi UNSRIT sebanyak 24 mahasiswa yang terdiri dari semester 1 hingga 7. Untuk saat ini proses perkuliahan dilaksanakan dengan cara tatap muka sebanyak 30\% dan secara online sebanyak 70\%. Dalam perkuliahan online, setiap dosen diwajibkan menggunakan google classroom sebagai media interaksi khususnya dalam pemberian materi tertulis, bahan perkuliahan, pemberian tugas, pengumpulan tugas.

Untuk mengukur efektifitas implementasi google classroom dalam penelitian ini, maka digunakan 4 indikator utama yaitu: reaction, learning, behavior dan result. Masing-masing indikator diberi pertanyaan untuk dijawab oleh mahasiswa selaku responden dalam penelitian ini, dengan criteria penilaian: Sangat Tidak Setuju (STS), Tidak Setuju (TS), Setuju (S) dan Sangat Setuju (SS)

\section{Tabel 1.}

Indikator dan pertanyaan dalam penelitian

\begin{tabular}{|c|c|}
\hline Indikator & Pertanyaan \\
\hline \multirow[t]{5}{*}{ Reaction } & $\begin{array}{l}\text { Menggunakan Google Classroom dapat mempercepat pekerjaan / menyelesaikan } \\
\text { tugas lebih cepat }\end{array}$ \\
\hline & Mengggunakan Google Classroom dapat meningkatkan produktivitas belajar saya. \\
\hline & Menggunakan Google Classroom dapat meningkatkan efektifitas belajar saya. \\
\hline & $\begin{array}{l}\text { Menggunakan Google Classroom dapat mempermudah saya dalam menyelesaikan } \\
\text { tugas-tugas kuliah. }\end{array}$ \\
\hline & $\begin{array}{l}\text { Menggunakan Google Classroom dapat mempermudah saya dalam menyelesaikan } \\
\text { tugas-tugas kuliah. }\end{array}$ \\
\hline \multirow[t]{5}{*}{ Learning } & $\begin{array}{l}\text { Menurut saya Google Classroom sangat membantu mahasiswa dalam proses } \\
\text { belajar }\end{array}$ \\
\hline & Penggunaan Google Classroom mudah dipelajari. \\
\hline & Saya dapat menggunakan Google Classroom sesuai dengan keinginan saya. \\
\hline & Tampilan Google Classroom sangat jelas dan mudah dipahami. \\
\hline & $\begin{array}{l}\text { Dengan Google Classroom, pengumuman, materi kuliah, tugas kuliah, maupun } \\
\text { pengumpulan tugas kuliah menjadi lebih fleksibel. }\end{array}$ \\
\hline \multirow[t]{6}{*}{ Behaviour } & Mudah bagi saya untuk mahir menggunakan Google Classroom. \\
\hline & $\begin{array}{l}\text { Saya merasa tidak sulit ketika mengecek apakah tugas yang saya kumpulkan telah } \\
\text { terkirim. }\end{array}$ \\
\hline & Informasi yang tertera di Google Classroom mudah saya pahami. \\
\hline & Dosen membagi segala informasi yang saya butuhkan melalui Google Classroom. \\
\hline & $\begin{array}{l}\text { Saya percaya pengguanaan Google Clasroom akan semakin sering digunakan di } \\
\text { masa depan. }\end{array}$ \\
\hline & $\begin{array}{l}\text { Dengan menggunakan Google Classroom saya merasa semakin bersemangat } \\
\text { dalam perkuliahan dan mengerjakan tugas-tugas }\end{array}$ \\
\hline
\end{tabular}




\begin{tabular}{|l|l|}
\hline \multirow{3}{*}{ Result. } & $\begin{array}{l}\text { Setelah menggunakan Google Classroom dalam proses perkuliahan saya semakin } \\
\text { paham bagaimana memanfaatkan teknologi dalam menambah ilmu dan } \\
\text { pengetahuan }\end{array}$ \\
\cline { 2 - 3 } & $\begin{array}{l}\text { Informasi materi yang disajikan melalui Google Classroom dapat membantu } \\
\text { mempelajari dan memahami materi kuliah. }\end{array}$ \\
\cline { 2 - 3 } & $\begin{array}{l}\text { Dosen memberikan tugas dan materi melalui Google Classroom sesuai dengan } \\
\text { silabus. }\end{array}$ \\
\cline { 2 - 2 } & $\begin{array}{l}\text { Mahasiswa merasa termotivasi menyelesaikan tugas melalui Google Classroom } \\
\text { karena ada tenggang waktu yang di berikan dosen. }\end{array}$ \\
\hline
\end{tabular}

Untuk hasil indikator reaction dari bobot pertanyaan yang diajukan maka sebanyak $95 \%$ mahasiswa merasa setuju bahwa penggunaan google classroom cukup memuaskan oleh karena kecepatan, produktifitas, efektifitas dan kemudahan yang diperoleh. Sisanya sebanyak $4 \%$ menyatakan sangat setuju bahwa google classroom memuaskan dalam penggunaannya sedangkan $1 \%$ menyatakan kurang setuju.

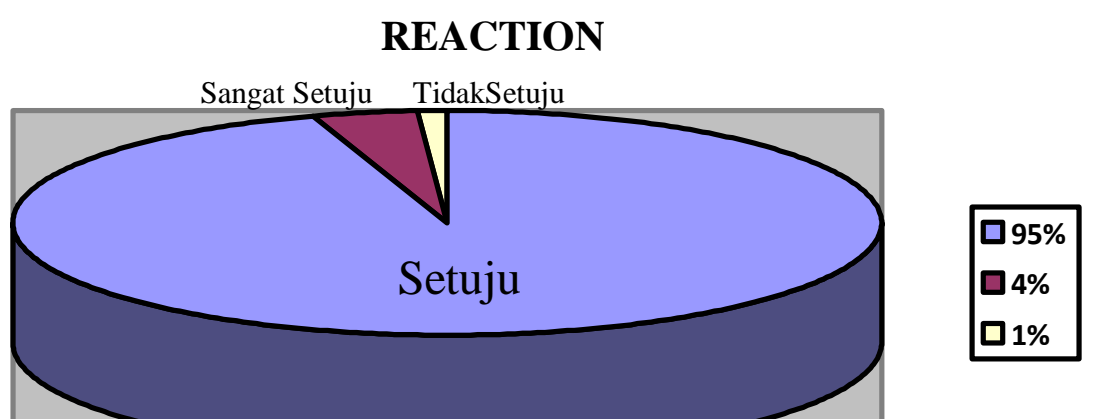

Grafik 1.

Perbandingan tingkat kepuasan penggunaan google classroom

Untuk hasil pada indikator learning maka dari pertanyaan yang diajukan ditemukan hasil penelitian bahwa sebanyak $82 \%$ mahasiswa merasa setuju bahwa penggunaan google classroom digunakan oleh Prodi Ilmu Komunikasi Universitas Sariputra Indonesia Tomohon oleh karena google classroom sangat membantu mahasiswa, mudah dipelajari dan sangat fleksibel dalam penggunaannya. Sebanyak $13 \%$ menyatakan sangat setuju sedangkan sebanyak $5 \%$ menyatakan tidak setuju. 


\section{LEARNING}
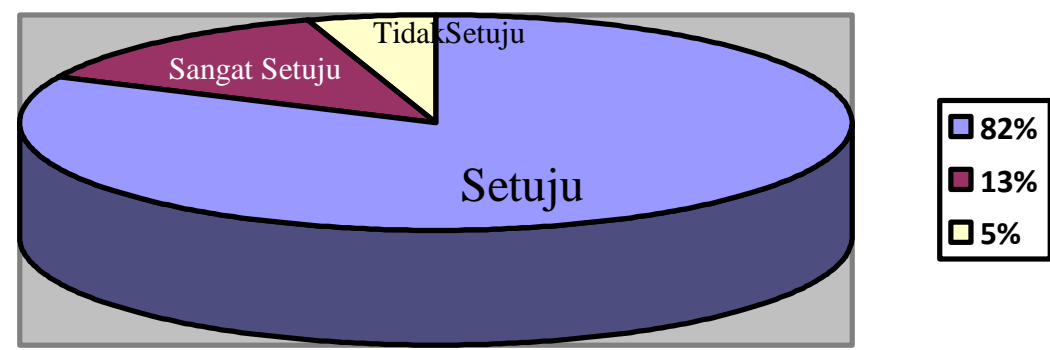

Grafik 2.

Tingkat persetujuan penggunaan google classroom pada Mahasiswa Prodi Ilmu Komunikasi UNSRIT

Pada indikator behavior maka ditemukan hasil sebanyak 78\% mahasiswa setuju bahwa terdapat perbedaan yang signifikan sebelum dan sesudah penggunaan google classroom dimana rerata mahasiswa sangat terbantu dan dimudahkan oleh penggunaan google classroom dalam perkuliahan yang mereka ikuti. Sebanyak $17 \%$ menyatakan sangat setuju untuk perbedaan sebelum dan sesudah penggunaan google classroom dimana terdapat kemudahan dalam proses belajar yang diberikan oleh dosen melalui google classroom. Sedangkan sisanya atau sebanyak 4\% menyatakan tidak setuju adanya perbedaan sebelum dan sesudah penggunaan google classroom dimana google classroom tidak memudahkan mahasiswa dalam perkuliahan.

\section{BEHAVIOR}
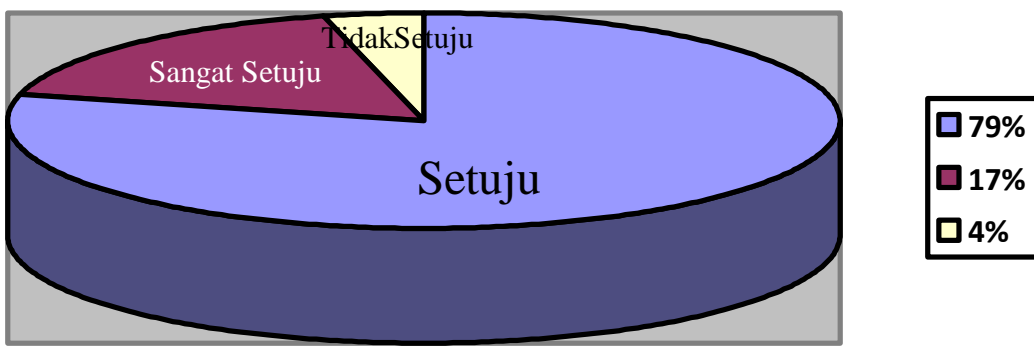

Grafik 3.

Tingkat persetujuan adanya perbedaan sebelum dan setelah penggunaan google classroom 


\section{RESULT}

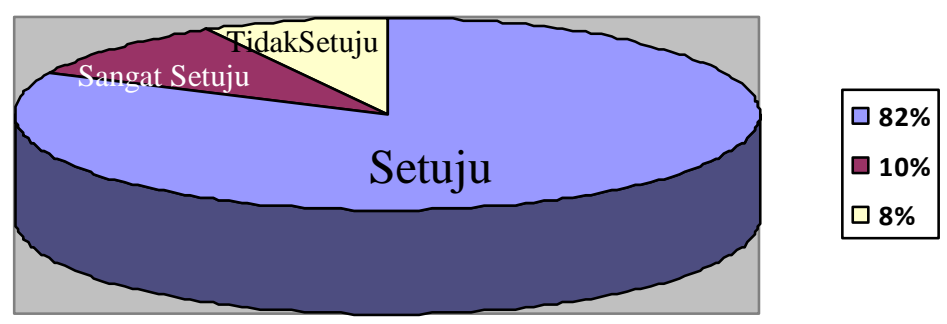

Grafik 4.

Tingkat persetujuan efektifitas penggunaan google classroom pada mahasiswa prodi Ilmu Komunikasi UNSRIT

Pada indikator result, melalui pertanyaan yang diberikan maka didapat hasil penelitian sebanyak $82 \%$ mahasiswa menyatakan setuju bahwa penggunaan google classroom pada prodi Ilmu Komunikasi Unsrit sudah efektif oleh karena ada semangat dalam pengerjaan tugas, semakin paham bagaimana memanfaatkan teknologi, informasi berupa materi dan silabus yang disajikan sesuai dan sangat membantu serta mahasiswa merasa termotivasi dalam pengerjaan tugas sebab ada tenggang waktu yang diberikan oleh dosen. Sebanyak 10\% menyatakan sangat setuju untuk efektifitas penggunaan google classroom sedangkan sebanyak $8 \%$ menyatakan tidak setuju.

\section{KESIMPULAN}

Dari hasil penelitian maka ditemukan fakta bahwa bagi mahasiswa Prodi Ilmu Komunikasi Unsrit google classroom sangat memuaskan dalam penggunaannya karena cenderung kecepatan, produktifitas dan kemudahan yang diperoleh. Oleh karena google classroom dapat diterapkan secara massif dalam perkuliahan di Prodi Ilmu Komunikasi bahkan di seluruh Prodi yang ada di Universitas Sariputra Indonesia Tomohon.

Kemudahan yang diperoleh dalam menggunakan google classroom meningkatkan pemahaman mahasiswa pada cara penggunaan google classroom dan membuat mahasiswa semakin paham cara memanfaatkan teknologi khususnya google classroom dalam pengerjaan tugas dan perkuliahan yang mereka ikuti. Sehingga dari pengalaman penggunaan google classroom ini dapat diimpulkan bahwa penggunaan google classroom dalam perkuliahan pada Prodi Ilmu Komunikasi Unsrit sudah efektif karena ada semangat dan motivasi pada mahasiswa dalam belajar maupun dalam mengerjakan tugas-tugas perkuliahan yang diberikan oleh dosen. 


\section{DAFTAR PUSTAKA}

Abdul Barir Hakim, (2016). Efektifitas Penggunaan E-learning Moodle, Google Classroom dan Edmodo. Jurnal I-Statement, Vol. 02, No. 01.

Bungin, B., (2010). Penelitian Kualitatif. 1 ed. Jakarta: Kencana.

Herman, Widya. (2014). Google Classroom Ruang Kelas di Dunia Maya. [online] tersedia: http://www.widyaherma. com/2014/10/google-classroom-ruang-kelas- di-dunia.html., Diakses, Minggu 18 Agustus 2019.

Pamungkas, Heri \& Hapsari, Swita, (2019). Pemanfaatan Google Classroom Sebagai Media Pembelajaran Online Di Universitas Dian Nuswantoro, WACANA, Volume 18 No. 2, Desember 2019, h. 225-233. ISSN: 2598-7402

Panduan pelaksanaan PJJ, http://spada.ristekdikti.go.id/s/berkas/view/1/panduan/pji, Diakses, Jumat 16 Agustus 2019

Panduan pengembangan \& penyelenggaraan, http://spada.ristekdikti.go.id/s/berkas/view/1/panduan/pengembangan_dan penyelenggaraan, Diakses, Jumat 16 Agustus 2019

Panduan penjaminan mutu, http://spada.ristekdikti.go.id/s/berkas/view/1/panduan/penjaminan_mutu, Diakses, Jumat 16 Agustus 2019

Sabran \& Edy Sabara, Keefektifan Google Classroom sebagai media pembelajaran. Prosiding Seminar Nasional lembaga penelitian Universitas Negeri Makassar, h. 122-125. ISBN : 978-602-5554-71-1

Vicky Dwi Wicaksono \& Putri Rachmadyanti, (2017). Pembelajaran Blended Learning Melalui Google Classroom di Sekolah Dasar. Prosiding Seminar Nasional Pendidikan PGSD UMS \& HDPGSDI Wilayah Jawa, h. 513-521. ISBN 978-602-70471-2-9

Yusuf Bilfaqih \& M. Nur Qomarudin, (2015). Esensi Pengembangan pembelajaran Daring, Ed. 1, Cet. 1. Yogyakarta: Deepublish. 